\title{
INTERPRETATION OF DISRUPTIVE INNOVATION IN THE ERA OF SMART CITIES OF THE FOURTH INDUSTRIAL REVOLUTION
}

\section{A ROMBOLÓ INNOVÁCIÓ ÉRTELMEZÉSE A NEGYEDIK IPARI FORRADALOM OKOS VÁROSAINAK KORSZAKÁBAN}

\author{
Gábor NICK ${ }^{\mathrm{a}}$, Ferenc PONGRÁCZ ${ }^{\mathrm{b}}$, Edit RADÁCS \\ ${ }^{a}$ Széchenyi István University Doctoral School of Regional and Economic, Address: Egyetem tér 1. Győr \\ H-9026, e-mail: nick.gabor@sze.hu \\ Institute for Computer Science and Control (SZTAKI), Hungarian Academy of Sciences (MTA). \\ Address: Kende u.13-17 Budapest H-1111 e-mail: nick.gabor@sztaki.hu \\ ${ }^{\mathrm{b}}$ Széchenyi István University Doctoral School of Regional and Economic, Address: Egyetem tér 1. Győr \\ H-9026, e-mail address: ferenc.pongracz@hu.ibm.com \\ ${ }^{c}$ Consultant, Address: Sárkeresztúri út 47/a Székesfehérvár H-8000, e-mail: edit.radacs@gmail.com
}

Cite this article: Nick, G., Pongrácz, F., Radács, E. (2018). Interpretation of Disruptive Innovation in the Era of Smart Cities of the Fourth Industrial Revolution. Deturope, 10(1), 53-70.

\begin{abstract}
The exponential development of information technology and, in this context, the latest generation of open innovation systems result in revolutionary changes in almost every industry as well as in other areas of life. From the automotive industry to the energy sector and to tourism, newcomers emerge everywhere, building on the tools of disruptive innovation, which with earlier unprecedented speeds transform their previous industry power.

The essence of the smart city approach is to put the latest tools of technological advancement in serving the social, economic and ecological sustainability of cities' lives for the inhabitants as well as for the enterprises of the city.

Industry 4.0 is an imagined future, which in our opinion - in direct or indirect ways - would have a fundamental influence on smart cities and their environment and regions, given that their primary goal is to improve a country's competitiveness.

In our study, we review the relevant literature on the definition of and approach to innovation as well as the smart city concept in this new revolutionary age, we demonstrate relevant correlations between the concepts of disruptive innovation, smart city and Industry 4.0.
\end{abstract}

Keywords: Smart City, Innovation, Industry 4.0

\begin{abstract}
Absztrakt
Az infokommunikációs technológiák exponenciális fejlődése és ezzel összefüggésben a nyílt innovációs rendszerek legújabb generációja forradalmi változásokat eredményeznek szinte minden iparágban. Az autóipartól az energetikán át a turizmusig mindenütt olyan új szereplők jelennek meg akik az úgynevezett romboló innováció (distruptive innovation) eszközeire építve korábban soha nem látott sebességgel alakítják át a korábbi iparági erőviszonyokat.

Az okos város megközelítés lényege, hogy a technológiai fejlődés legújabb eszközeit a városok életének társadalmi, gazdasági és ökológiai fenntarthatóságának szolgálatába állítsa a városok lakói és az ott működő vállalkozások érdekében. A romboló innováció korszaka új kihívásokat és lehetőséget teremt és várhatóan a globalizáció korábbi hullámainál is jelentősebb változásokat hoz a városok számára.

Az Ipar 4.0 egy elképzelt, megálmodott jövő, amely, véleményünk szerint - közvetlen vagy közvetett módon -, elementáris hatást gyakorol az okos városokra, azok környezetére és régióira, melyek elsődleges célkitüzése az ország versenyképességének javítása.

Tanumányunkban áttekintjük az Innováció definíciójának vonatkozó szakirodalmát ebben az új forradalmi korban, majd releváns példák bemutatásával igazoljuk hipotézisünket az iparági erőviszonyokat illetően.
\end{abstract}

Kulcsszavak: Smart City, Innováció, Ipari forradalom 4.0 
Nick, G., Pongrácz, F., Radács, E.

\section{INTRODUCTION/ OBJECTIVES AND METHODS}

In our view, there are two key driving forces behind the rapid global economic, political and environmental changes we are experiencing: demography and Info-Communications Technologies (ICT).

The role of the cities has become more important and all the sustainability issues have relevant urban dimensions. By utilizing ICT options environmental, social and economic sustainability issues can be handled and solved at higher level, however, this cannot be done without the capability for radical/disruptive innovation. The radical innovation vision of Industry 4.0 is a response to the global competitiveness challenges, which also requires a supporting infrastructural and social environment having urban dimensions as well.

The concept of smart cities is an answer for the environmental, economic and social sustainability issues generated by the previously listed challenges. Smarter cities are utilising ICT technologies and in order to do so they need to innovate.

The exponential development of the Info-Communications Technologies itself is a result of innovation and as an additional layer, creative adoption of the new technologies in order to solve issues also requiring innovation. The modern networked, collaborative innovation processes are strongly connected to innovation ecosystems ${ }^{1}$ that are typically linked to metropolitan areas.

Industry 4.0 concept is also about development of the innovation capabilities with special industrial focus. While Industry 4.0 is originally not a city-focused vision, the targeted network of smart factories is also linked to cities both as research and development centres and also as locations of the new smart factories.

In our study, reviewing the relevant literature on the definition of and approach to disruptive innovation, to Industry 4.0 as well as the smart city concept we intended to demonstrate relevant correlations between these factors. Deep discussion of definition of each key components of the study (innovation, Industry 4.0, smart city) is beyond the framework of this article. Our focus is the connection between the mentioned concepts. In order to do so we analyse the overlaps between the measurement methods related to innovation, Industry 4.0 and smart cities with a comparative table. We also visualise the correlations with a conceptual chart.

\footnotetext{
${ }^{1}$ Innovation ecosystem is the term used to describe the large number and diverse nature of participants and resources that are necessary for innovation. These include "entrepreneurs, investors, researchers, university faculty, venture capitalists as well as business development and other technical service providers such as accountants, designers, contract manufacturers and providers of skills training and professional development" source: http://www.know-hub.eu/knowledge-base/videos/innovation-ecosystems-as-drivers-of-regionalinnovation-validating-the-ecosystem.html
} 


\section{RESULTS}

\section{Demographic challenges}

The 7 billion population of the world in 2010 is expected to grow over 10 billion by 2060 and over 11 billion by $2100.80 \%$ of this growth is forecasted to come from Africa. According to the United Nations, Department of Economic and Social Affairs, Population Division 2015 forecast the population of Europe meanwhile is expected to decline from the 735 million in 2010 below 650 million by 2100. Historically between 1950 and 2010 the world has experienced proportionally an even more radical shift in population when the world population increased from 2.5 billion to 7 billion driven by a close to 3 billion population growth in Asia. (United Nations, 2015). Population growth in combination with globalisation and the ICT revolution that impacted all other industries resulted very significant economic growth and improving living standards on one side and very serious environmental issues on the other side including non-sustainable usage of natural resources and alarming level of global warming.

\section{Technology development}

The earlier wave of the ICT revolution starting with the personal computers followed by the rapid extension of the internet combined with the liberalization of world trade and the global logistic networks resulted the global economy as we know it today utilizing technology enabled global scale labour arbitrage as one of its key drivers.

ICT is not just one of the fastgrowing industries or disciplines but plays key role in the fundamental changes we are experiencing in the global economy. ICT is in a unique position, firstly because of the exponential technological development of the performance of the basic electronic components often referred to as the Moore's Law ${ }^{2}$ and secondly because ICTs are the key drivers of the revolutionary development of all domains from medicine through energy distribution to the automotive industry. Experts predict that this exponential development will continue at least in the next 10-15 years.

Probably the most well-known description of the intensifying changes caused by the disruptive ICT based innovation ${ }^{3}$ is the Wall Street Journal article by Marc Andreessen published in 2011: Why Software Is Eating the World. In his visionary article Andreessen predicted that „more and more major businesses and industries are being run on software and

\footnotetext{
${ }^{2}$ Moore's Law is a computing term which originated around 1970; the simplified version of this law states that processor speeds, or overall processing power for computers will double every two years. (http://www.mooreslaw.org/)

${ }_{3}^{3}$ Disruptive Innovation refers to a technology whose application significantly affects the way of market or industry functions. A disruptive innovation is differentiated from a disruptive technology in that it focuses on the use of the technology rather than the technology itself. ( https:/www.investopedia.com/terms/d/disruptive-)
} 
delivered as online services - from movies to agriculture to national defence. Many of the winners are Silicon Valley-style entrepreneurial technology companies that are invading and overturning established industry structures. Over the next 10 years, I expect many more industries to be disrupted by software, with new world-beating Silicon Valley companies doing the disruption in more cases than not." (Andreessen, 2011, p.1.). Several years later it is enough to have a look at the changes on the list of the top 10 global companies by market value to appreciate software has been really eating the world.

Software-enabled innovation is reshaping almost all industries. Automotive, the segment that plays dominant role in continental Europe and especially in Central and Eastern Europe is not an exception.

As Mary Barra (2016), the Chief Executive Officer of General Motors has stated, car industry is going to go through more changes in the next 10 years, than it had in the last 50 years. Barra emphasizes the following technological trends:

- $\quad$ Electro mobility: Combustion engine cars are a thing of the past

- Connected Car: Cars "communicate with each other" - Continuous, automated data collection and mobile communication

- $\quad$ Autonomous car: Self-driving cars

- $\quad$ Car sharing: Instead of owning vehicles, emergence of as a service based business model (Barra, 2016).

Changes occur not only in automotive industry. Nowadays $90 \%$ of all production processes are also supported by some kind of ICT tools. The increasingly significant and essential role of ICT applied by companies has changed the life and working conditions. Miniaturization and the development of communication technologies enable the blending of the physical and the virtual world and by creating a new, so-called CPS - Cyber-Physical System, in which physical space has an especially important and defining role. Industrial production becomes now to be integrated into an intelligent environment called 'smart factory'.

Based on this technological evolution, Germany announced the arrival of Industry 4.0 vision, with its core element being the integration of CPS into the production and logistics systems, as well as the introduction of the network of tools and services in the production processes, influencing value production, business models, organizational structures, decision making and communication mechanisms, creating a change of paradigm of such a degree, which can rightly be called the fourth industrial revolution.

There can be observed similar revolutionary changes in a couple of other industries such as energetic and public utilities (spread of renewable energy production, distributed energy production model, "smart grid"), media and entertainment (social media, video streaming vs. 
traditional media), tourism and transportation (emergence of new software enabled business models represented rapidly emerging new players like Airbnb or Uber for example).

\section{Role of the cities}

Beyond the previously mentioned growth and shift of geographic distribution of the global population there is an additional trend: the increasing level of urbanization. Today more than half of the global population lives in cities. While in $1950,30 \%$ of the world's population was urban, by $2050,66 \%$ is projected. Urban population is expected to grow by 2.5 billion by 2050, with nearly $90 \%$ of the increase concentrated in Africa and Asia. "As the world continues to urbanize, sustainable development challenges will be increasingly concentrated in cities, particularly in the lower-middle-income countries where the pace of urbanization is fastest", (United Nations, 2015, p. XXI.). Besides the mentioned demographic changes knowledge and innovation capabilities are also concentrating in few numbers of cities that are becoming global knowledge and innovation centres with innovation ecosystems of global impact (Start-up genome, 2017).

\section{Cities - basic centres of innovation and development}

The development of cities in Europe was motivated by several factors. Demographic growth, technological development, and demand for living in a community, requirement of security as well as interest representation should be highlighted. Although centuries have evolved and changed, essential functions of cities have remained so nowadays.

For interpreting success at city level (Rechnitzer, Smahó, 2004; Enyedi, 1996), the following factors can be considered:

- Quick change of structure

- Strong innovation capability

- Decision-making power

- Knowledge-based production

- Urban society, strong and prosperous middle class

- Employment and income growth

- External, global relationships

Rechnitzer and Smahó (2011) also state, the city is competitive, if it is successful, furthermore they lay emphasis on urban, regional strategy making, future research and preparation, and on the role of innovation as a whole. The current rapid technological development has necessitated the evolvements of smart cities (and their regions) that have to provide and perform manifold tasks: they should not only adopt novelties, but also initiate and promote innovation activities. This, of course, implies a significant change in certain 
functions, roles, way of thinking as well as attitudes, which is inherent in the previously mentioned destructive innovation.

Based on this Etzkowitz and Leydesdorf (1997) introduced the Triple-Helix model defining three main distinctive entities:

- University

- Enterprise

- Government

According to the interactions between the actors they identified three structures as follows:

- Structure I: the state (government) controls and there is no bottom-up innovation. There can be a strong, government-driven demand for innovation (former SovietUnion) and can be a weaker one (some Latin American countries).

- Structure II: there are strong boundaries, fixed links between the actors. This can be well observed in the USA and in Sweden.

- Structure III: this form can be characterized by overlapping, clusters, common purposes. This is a criterion of countries consciously planning future. The main goal of the actors is cooperation by reducing impediment factors in order to have common development orientation.

We consider, even this Structure III describes and defines the interactions of the knowledge-based economy development (David, Foray, 2002; OECD 1996), the development of collaborative networks that utilize the values of one another and build business processes as well as knowledge transfer. Although the role of universities and governments in the first two industrial revolutions was small, in the age of digitization it can already be observed, that their significance is fundamental: without government or university research there would be no Internet today, for example.

The trend necessitates more and closer cooperation between the three actors, which can be made in the form of networking links or by creating of clusters. Government is expected to play supporting role; enterprises have to identify the innovation potentials as well as to define goals and directions. Industry companies, as purchasers of R\&D\&I activities, can serve as a major engine for a new knowledge-based economy in a knowledge-based society (David, Foray, 2002), contributing to the emergence of a digital ecosystem and thereby promoting the country's competitiveness (Lengyel, 2010).

Industrial development policies of dominant European countries (Kagermann, Wahlster, Helbring, 2013; Roland Berger, 2014) are based on wide-ranging relations between research centres (academia centres, universities, and research institutes), state administration (government) and industry. Innovation potential and the primary depositories of the related 
economic development are the research sites, however, changes, challenges and new opportunities can only be tackled if industrial enterprises and the state are involved in production, knowledge transfer and new institutional and social forms of applications.

Some specific examples of links between/among Triple-Helix members:

- Research Centre - Industry: joint R\&D\&I tenders and projects; patterns and factories

- Research Centre - State: targeted state aid for financing specific research activities

- Research Centre - Industry - State: operation of technology platforms, participation in R\&D\&I excellence programs

\section{Innovation - creative destruction - disruptive innovation}

A century ago, the first economic theory approach to innovation can be linked to Schumpeter, the Austrian-born American economist. In 1911 (Schumpeter, 1980) his starting point was that the economic cycle can be fundamentally interpreted as an equilibrium situation. Manufacturers are basically not interested in any creative activity; they are focusing purely on satisfying the only quantitatively changing needs of their consumers. Schumpeter used the term „development” (Schumpeter, 1980), that should be considered as a separate phenomenon, which is absonant from all other phenomena observable during this cycle or in tendencies towards equilibrium.

Development is a spontaneous, shocking change of the proces's path, a disturbance of balance, which once and for all modifies, relocates the existing equilibrium situation.

Schumpeter defines innovation as the following five events - as well as the combination thereof:

- Introduction of a new product or a new product quality

- Introduction of a new production method, however, it might consist a new way of treating a product commercially

- The opening up of a new market

- The opening up of a new source for raw materials or semi-manufacture regardless of whether the source has existed before

- The creation of new organizational structure in industry, for example by creating or breaking down a monopoly situation

"Creative destruction" was introduced in Schumpeter's (1942) book: Capitalism, Socialism and Democracy. Schumpeter used it to describe the disruptive process of transformation that accompanies such innovation. Innovative entry by entrepreneurs was the disruptive force that sustained economic growth even as it destroyed the value of established companies and labourers that enjoyed some degree of monopoly power. 
In the mid 1990s Christensen introduced the expression of "disruptive innovation". It refers to an innovation that creates a new market and value chain and at the same time disrupts the existing ones. According to Christensen a disruptive innovation can be interpreted as a product or service designed for a new set of customers (Christensen, 1997)

The process of the disruptive innovation can be described as follows:

- Innovation centres of market leaders develop the latest, smaller size technologies mainly technically straightforward and simpler than the older ones -, but after unsuccessful market tests they stop the developing process.

- New companies (outsiders, entrepreneurs) begin to invest into the uncertain, new and unexploited technologies and try to attract customers.

- If they put their feet on the market with the new product, they develop it by 'sustaining' innovation.

- When the novelty reaches the old product's market indicators, it rapidly starts to cannibalize the market of the older one.

- Manufacturers of the old products notice the technology change too late and are not able to make up the lagging anymore.

The failure of successful companies is caused by the non-allocation of sufficient resources into innovations based on technologies which cannot be used on the current market of the company. Being afraid of ambiguous success as well as because of limited motivation they do not invest in such innovation development. However, companies are able to avoid disruptive innovation if they invest resources into searching for new opportunities during the company's growth period and manage projects in proper manner (Christensen, Bower, 1996).

At the turn of the millennium OECD countries summarized the results of their comprehensive research in a book also known as Oslo Manual (2005) containing guidelines for collecting and using data on industrial innovation. The first edition was focusing essentially on product and process innovation in manufacturing technology.

The European Commission has also joined the relevant researches and the revised manual was published in 2005 introducing the concept of marketing, organizational and management innovation and the conception of knowledge transfer networking as well.

In the Hungarian relevant literature (László Gáspár, 1988) considers innovation as a universal activity that at the same time represents the renewal of the economic, political and cultural spheres.

János Rechnitzer (1993), by widening the above mentioned concepts, points out that innovation can be interpreted as new human and community behaviours. As the actors of innovation as well as their functions are changing, it is irrelevant what the new product is. The 
question is whether this novelty was unknown to the given social groups or economic actors or not.

He specifies the types of innovation in the following grouping:

- Economic-organizational: an environment where all the institutional conditions are given for the free spread of innovation, for example act of free company establishment (foundation)

- Product: in addition to new technical products the novelties of production control can be interpreted within this frames

- Activity: non-materialized knowledge and new information for improving economic and life functions

- Social-political: improvements related to community living spaces beyond the individual, for example the changes in Hungary in 1989

As the milieu of innovation (Rechnitzer, 1993) can be interpreted on the one hand those economic and production relations that homogenize the production culture, thereby gaining mutual knowledge and increasing their mutual trust network, on the other hand existing features that are present in the local social relations, culture and institutional system. These are all the factors that cities can provide.

The European Digital City Index (EDCI) describes how well different European cities support digital entrepreneurship. For start-ups and scale-ups, it provides information about the strengths and weaknesses of local ecosystems, allowing them to plan accordingly and consider where they may need to devote more resources. For policy makers aiming to encourage digital entrepreneurship in their own city, the Index helps identify existing and promising hubs of activity, in order to learn from their practices. Additionally, it allows benchmarking of performance against other European hubs, and helps identify which policy areas to prioritize. (European Digital City Index, 2016)

"The Digital Economy and Society Index is a composite index that summarizes relevant indicators on Europe's digital performance and tracks the evolution of EU member states in digital competitiveness."(https://ec.europa.eu/digital-single-market/en/desi) The composite index contains five differently weighted dimensions: Connectivity, Human Capital / Digital Skills, Use of Internet by citizens, Integration of Digital Technology by businesses, Digital Public Services. The DESI aims to assist EU countries in identifying areas requiring investments and actions for creating a Digital Single Market. Based on DESI, comparing to worldwide results Europe is becoming more digital, for example the top EU countries (Denmark, Sweden, and Finland) are also top worldwide performers in digital. But, as a whole, the European Union needs to improve in order to catch up with the most digitized countries in the world (Japan, South Korea, and the USA). DESI is not a city level indicator, 
but its structure can be used when we make comparison with city level indexes therefore we mention it here.

Global Start-up Ecosystem Report is a comprehensive analysis of the leading global startup ecosystems. It is based on more than 100 indicators that are grouped into the following main categories: 1) Performance, 2) Funding, 3) Market Reach, 4) Talent, 5) Start-up Experience (Start-up genome, 2017).

The Global Innovation Index (GII) provides detailed metrics about the innovation performance of 127 countries and economies around the world. Its 81 indicators explore a broad vision of innovation, including political environment, education, infrastructure and business sophistication. (Soumitra et al., 2017)

Global Start-up Ecosystem Report (GSER) is published by a private research organisation called Start-up Genome and its conclusions are based on data from 10,000 start-ups and 300 partner companies. The global survey includes data from thousands of start-ups across 56 ecosystems, as well as data via partnerships such as Crunch Based and Deal Room. (Start-up Genome, 2017)

\section{Industry 4.0}

The industry of Europe in the $21^{\text {st }}$ century faces significant challenges. The ever-decreasing raw material supply, the rising energy prices and the demographic changes require the modification of the existing model. The increasing competition mostly driven by the increasing productivity of the Asian industry and innovation makes it clear that the production industry needs solutions it can efficiently respond to challenges with (McKinsey \& Company, 2013).

The following factors in our opinion post a challenge to the industry of the $21^{\text {st }}$ century (United Nations, 2011):

- Global competition

- Market volatility

- Customized products

- Time-to-market and delivery performance (speed)

- The sustainability of the full life cycle of products

- Productivity (resource-efficiency, value orientation)

- Shortage of skilled labour

The production systems have been gradually complemented with information technology support tools in recent decades, as increasingly complex technological solutions, production in often multiple locations and the coordination of supporting logistics processes started to pose an ever-more complex challenge. Accordingly, $90 \%$ of all production processes are now 
supported by ICT tools. The increasingly dominant and pivotal role of ICT in companies has changed lifestyles and working environment, the significance of which is unquestionable.

Miniaturization and the development of communication technologies enable the blending of the physical and virtual world and give way to the so-called CPS - Cyber-Physical System. Industrial production becomes to be integrated into an intelligent environment called 'smart factory' in the related literature.

Based on this technological evolution, Germany announced the arrival of Industry 4.0, also called the fourth industrial revolution.

The 2011 Hannover Expo opened a new era for the German industry due to the public debut of the scientific project called Industry 4.0. According to the concept the smart factories of the future will produce smart products for the global market. Deeper horizontal and vertical integration is expected from every member of the value chain while the collaboration will move to a service based model. Physical and virtual worlds are converging and the product itself becomes intelligent and it will control the production. Personalized, customized products are going to be produced using advanced mass production technologies.

The evolution of ICT, the smarter and smaller devices (Smart Devices), the growing role of the Internet as well as the emergence of cloud-based computing technology and services (Cloud-Computing) further enhance the importance of computer data processing and information systems in the industry. The ever-smaller microcomputers, embedded systems communicate wirelessly over the Internet resulting in a new system called Cyber-Physical System (CPS).

Instead of a uniform mass production both in manufacturing as well as in services those ones gain advantageous positions that may combine the cost advantages resulting from automation and modern work organization methods with tailor-made solutions for their customers.

Potential customers should be very well known and the planning of products and services should be built around the customer needs. Instead of looking for customers for a single product or technology, we have to know the often hidden requirements, and to look for real solutions providing much more than what currently is available. A good example is the famous saying associated with Henry Ford: "If I had asked people what they wanted, they would have said they would have a faster horse." (Schoonmaker, 2014)

For measuring and estimating of innovation willingness and readiness of countries, regions as well as cities, Roland Berger (2014) created the "RB Industry 4.0 Readiness Index". The index uses the following sets of indicators when creating a so-called country ranking.

1. Industrial excellence:

- Production process sophistication 
- Degree of automation

- Workforce readiness

- Innovation intensity

2. Value network:

- High value added

- Industry openness

- Innovation network

- Internet sophistication

\section{Smart Cities}

The concept of the smart city has become increasingly widespread today. As a starting point, we may use the internationally known ITU-T/FG SSC Smart City definition from 2014 which was based on the evaluation of 116 different definitions developed by researchers, government bodies, international IT companies, and other practitioners. (Kondepudi et al. , 2014.)

"A smart sustainable city (SSC) is an innovative city that uses information and communication technologies (ICTs) and other means to improve quality of life, efficiency of urban operation and services, and competitiveness, while ensuring that it meets the needs of present and future generations with respect to economic, social and environmental aspects".(https://www.itu.int/en/ITU-T/focusgroups/Documents/Approved-Deliverables/TRDefinitions.docx)

The smart city concept is co-created by corporations (like IBM, Siemens, CISCO and recently multiple Chinese ICT giants), players from all layers of public administration and international organizations from city level up to the European Union/United Nations and it is also a scientific concept developed by scholars. It is worth to mention, that like most of the popular concepts, smart city approach has its critics as well highlighting among others the security and data privacy issues raised by the extensive usage of networked smart devices and sensors.

As one of the leading global corporations IBM has played a significant role in developing the smart city concept. By announcing the launch of the "Smarter Planet" initiative in 2008 they were aiming more efficient and reliable solutions of social, environmental, economic problems through the latest advances in ICT. The three main features of Smarter Planet solutions are marked with three "i", based on English initials: instrumented, interconnected and intelligent operation. 
One of these elements is a smart city focusing on responses to urban challenges. The Smart City Assessment methodology of IBM examines the operation of the city at three levels (Dirks, Keeling, 2009):

- The mission and direction (government) of the city (City Operation Systems)

- Services used by the inhabitants and enterprises operating there (City User Systems)

- The infrastructure supporting the above (City Infrastructure Systems)

Based on the above smart technologies are not viewed by themselves only, but from the point of view whether they support the realization of the goals of a city strategy, as well as how they serve the city's inhabitants and enterprises.

The methodology suggests taking into account systematized indicators based on following aspects:

- $\quad$ Prerequisites (preconditions)

- Management

- "Smart" systems

- $\quad$ Results, achievements

The aspect "Smart systems" should be emphasized because according to our interpretation without the innovative application of ICT we cannot speak of a smart city

As a trigger of global social and economic changes, we highlight two factors: knowledge as a non-conceivable production factor and the appreciation of the role of ICT, which together require a new kind of thinking about the digital economy. This is confirmed by the Smarter Cities Study commissioned by IBM Hungary (Lados, Horváthné, 2011). City and ICT support each other in order to achieve common success by realizing livable or smart city as a goal to be achieved.

Numerous organizations and research groups published smart city and sustainable development indexes that are following similar logic and often overlapping sets of indicators. A list of some of these rankings:

- $\quad$ TU Wien European Smart Cities Ranking

- $\quad$ Smart City Index by Boyd Cohen

- $\quad$ IBM Smarter City Assessment

- ISO 37120:2014 Sustainable development of communities - Indicators for city services and quality of life

- $\quad$ Smart City Index Italy by Between

- $\quad$ Sustaina 100 by Sustaina

- $\quad$ Sustainable Development Goals by United Nations

The Technical University of Vienna (Technische Universität Wien, TUW) (Giffinger at al., 2007) is one of the leading scientific centres in 'smart cities' research, where the Smart City 
Ranking (SCR, TUW SCR), a kind of competitiveness, "smartness" index of European cities derived from a system of indicators chosen by the researchers is regularly published. They defined six basic characteristics in their research (Figure 1) (Giffinger at al., 2007):

- $\quad$ Smart Economy

- $\quad$ Smart Governance

- Smart People

- Smart Mobility

- $\quad$ Smart Environment

- $\quad$ Smart Living.

These are weighted and represent the current and relative ranking among the cities involved, considering the criteria of smart cities.

Figure 1 Relationship between technology development, demographic shifts and sustainability issues

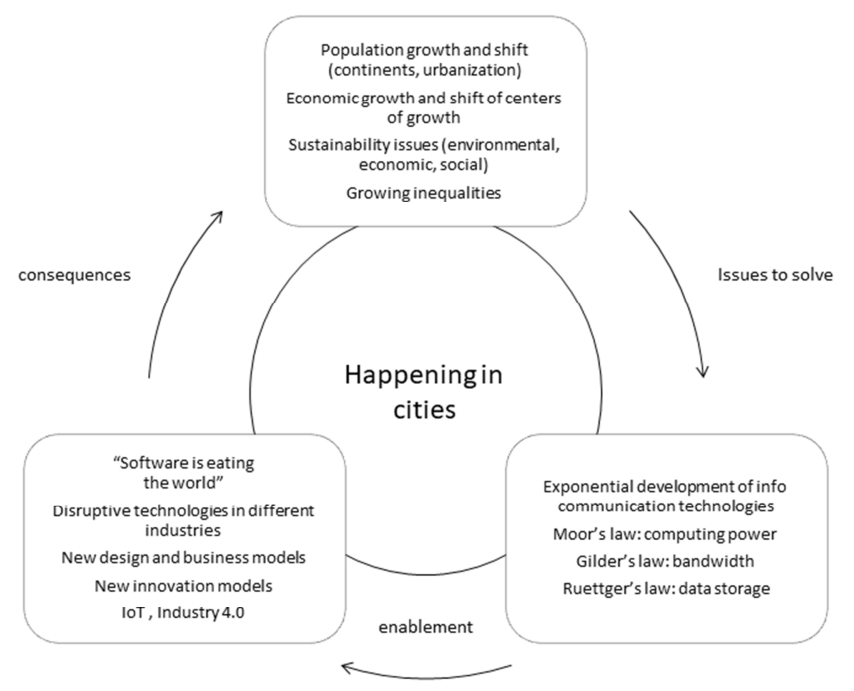

Source: edited by authors

Varying numbers of towns are chosen from different European countries, but they fundamentally have to meet certain criteria in order to be considered for the annual assessment:

- $\quad$ The city's population must be between 100 and 500 thousand

- $80 \%$ of the data pertaining to the indicators must be available

- The city must be included in the Eurostat Urban Audit Database

- Must have at least one operational university

Factors are assigned to the characteristics, data for which is derived from indicators. For example, within the Smart Economy Characteristic (competitiveness), having interest to this paper, we can find the Innovative Will factor, which comes from three NUTS2 indicators:

- $\quad$ R\&D expenditure in \% of GDP 
- $\quad$ Employment rate in knowledge-intensive sectors

- $\quad$ Patent applications per inhabitant

Innovation is present here as well, as a highlighted evaluation point of view of cities. (Giffinger et al., 2007)

ISO 37120:2014 standard (https://www.iso.org/standard/62436.html) defines and establishes methodologies for a set of indicators to steer and measure the performance of city services and quality of life. ISO 37120:2014 is applicable to any city, municipality or local government that undertakes to measure its performance in a comparable and verifiable manner, irrespective of size and location.

\section{CONCLUSION}

Human race experienced unparalleled technological development and partially as a result of it unparalleled population expansion and economic growth during the decades behind us. Both the distribution of the population growth and the distribution of the incremental income and wealth are geographically uneven. Besides population growth we are also experiencing very extensive urbanization as well. The importance of the cities has been continuously increasing as by now more than $50 \%$ of the global population is living in cities while $70 \%$ of the global GDP is generated in urban areas. This concentration is expected to continue. The radical changes are generating very serious issues in the area of environmental sustainability while economic and social inequality is also becoming more and more serious concern.

Base technologies like computing power (Moor's law), bandwidth (Gilder's law ${ }^{4}$ ), and data storage capacity (Ruettger's law $^{5}$ ) have been developing on exponential speed. Besides the development of these technologies new innovation and business models have emerged that are resulting radical changes of the status quo in almost all industries and geographical areas. This phenomenon is often called disruptive innovation.

We believe that the concept of smart cities and also Industry 4.0 are strongly correlated to the concept of disruptive innovation.

- The importance of the cities has been increasing and most of the sustainability issues has very strong urban dimension as well. The smart city initiative is about utilizing Info-Communications Technology enabling solutions to handle environmental, social

\footnotetext{
${ }^{4}$ An assertion by George Gilder, visionary author of Telecosm, which states that "bandwidth grows at least three times faster than computer power." This means that if computer power doubles every eighteen months then communications power doubles every six months. Source: https://www.netlingo.com/word/gilders-law.php

${ }^{5}$ Ruettger's law of storage states, that companies double they storage needs every 12 months Source: Applying E-Commerce in Business By Rana Tassabehj p. 274
} 
and economic sustainability issues. This cannot be done without the capability for radical/disruptive innovation.

- The concept of Industry 4.0 is an attempt of the German/European industry to respond global competitiveness challenges. It is about innovative application of the exponentially developing Info-Communications Technologies in the industrial value chain. Industry does operate also in urban environment and most of the prerequisites of implementing a radical innovation vision like Industry 4.0 require a supporting infrastructural and social environment that has a very important urban dimension as well.

Analyzing some of the practical measurement methods related to city performance, smart cities, Industry 4.0 and city innovation capabilities, we found that there is a very significant overlap between the indicators (Tab. 1). The indicators typically applied to assess innovation capabilities are very much the same as the ones measuring and ranking smart cities and also there is a remarkable overlap with the Industry 4.0 indicators we observed. It seems to confirm the correlation between innovation capabilities and the concept of Smart Cities and Industry 4.0.

Table 1 Comparison of innovation, Smart City and Industry 4.0 indicators

\begin{tabular}{|c|c|c|c|c|c|c|c|}
\hline \multicolumn{4}{|c|}{ Innovation Indexes } & \multicolumn{3}{|c|}{ Smart City Indexes } & \multirow{2}{*}{\begin{tabular}{|r|} 
Industry 4.0 Index \\
Roland Berger
\end{tabular}} \\
\hline GII & EDCi & DESI & GSER & $\begin{array}{c}\text { Technical University } \\
\text { of Vienna }\end{array}$ & $\begin{array}{l}\text { IBM Smart City } \\
\text { Assessment }\end{array}$ & ISO 37120 & \\
\hline Institutions & $\begin{array}{l}\text { Business } \\
\text { Environment }\end{array}$ & $\begin{array}{l}\text { Digital Public } \\
\text { Services }\end{array}$ & Funding & Smart Governance & City Services & $\begin{array}{c}\text { Governance/Fire and } \\
\text { Emergency } \\
\text { Response/Urban } \\
\text { Planning }\end{array}$ & \\
\hline $\begin{array}{c}\text { Human Capital and } \\
\text { Research }\end{array}$ & Skills & Human Capital & Talent & Smart People & Citizens & Education/Health & workforce readiness \\
\hline \multirow{3}{*}{ Infrastructure } & Digital Infrastructure & $\begin{array}{c}\text { Conectivity/Use of } \\
\text { Internet }\end{array}$ & & & Communication & Telecommunication & $\begin{array}{c}\text { Internet } \\
\text { sophistication }\end{array}$ \\
\hline & $\begin{array}{l}\text { Non-Digital } \\
\text { Infrastructure }\end{array}$ & & & $\begin{array}{c}\text { Smart Mobility/Smart } \\
\text { Environment }\end{array}$ & Water/Energy & $\begin{array}{c}\text { Energy/Environment/ } \\
\text { Shelter/Solid } \\
\text { Vaste/Wastewater/ } \\
\text { Water and Sanitation }\end{array}$ & \\
\hline & Lifestyle & & & Smart Living & & Recreation & \\
\hline \multirow{2}{*}{$\begin{array}{c}\text { Market } \\
\text { Sophistication }\end{array}$} & Access to Capital & & & & & & \\
\hline & Market & & Market Reach & Smart Economy & & Economy & \\
\hline \multirow{2}{*}{$\begin{array}{c}\text { Business } \\
\text { Sophistication }\end{array}$} & $\begin{array}{l}\text { Enterpreneural } \\
\text { Culture }\end{array}$ & & Startup Experience & & \multirow[b]{2}{*}{ Enterprises } & & Industry opennes \\
\hline & $\begin{array}{l}\text { Mentoring and } \\
\text { Managerial } \\
\text { Assistance }\end{array}$ & & & & & Finance & \\
\hline $\begin{array}{l}\text { Knowledge and } \\
\text { Technology output }\end{array}$ & Knowledge Spillovers & $\begin{array}{c}\text { Integration of Digital } \\
\text { Technology }\end{array}$ & & & & Innovation & $\begin{array}{l}\text { production process } \\
\text { sophistication }\end{array}$ \\
\hline Creative outputs & & & Performance & & & & $\begin{array}{c}\text { innovation } \\
\text { intensity/innovation } \\
\text { Network } \\
\end{array}$ \\
\hline & & & & & & & degree of automation \\
\hline
\end{tabular}

$\begin{array}{ll}\text { EDCI } & \text { European Digital City Index } \\ \text { DESI } & \text { Digital Economy and Society Index } \\ \text { GSER } & \text { Glogal Startup Ecosystem Report } \\ \text { GII } & \text { Global Innovation Index } \\ \text { ISO } 37120 & \text { City indicators for service delivery and quality of life } \\ \text { Roland Berger } & \text { RB Industry 4.0 Readiness Index }\end{array}$

Source: edited by authors based on the mentioned data sources 


\section{REFERENCES}

Andreessen M. (2011). Why Software Is Eating the World, The Wall Street Journal August 20, $2011 \quad$ Retrieved from https://www.wsj.com/articles/SB10001424053111903480904576512250915629460

Barra M. (2016). The next revolution in the auto industry Retrieved from https://www.weforum.org/agenda/2016/01/the-next-revolution-in-the-car-industry/

Blanchet, M., Rinn, T., Von Thaden, G., De Thieulloy, G. (2014). Industry 4.0 The new industrial revolution How Europe will succeed. Roland Berger Strategy Consultants. Retrieved from https://www.rolandberger.com/publications/publication_pdf/roland_berger_tab_industry 4_0_20140403.pdf

Christensen C. M. (1997). The innovator's dilemma: when new technologies cause great firms to fail. Harvard Business School Press, Boston

Christensen, C.M., Bower, J.L. (1996). Customer Power, Strategic Investment, and the Failure of Leading Firms. Strategic Management Journal, 17(3), 197-218

David, P. A., Foray, D. (2002). An introduction to the economy of the knowledge society.

Dirks S., Keeling M. (2009). A vision of smarter cities. IBM Institute for Business Value. Somers, USA.

Enyedi Gy. (1996). Regionális folyamatok Magyarországon, Hilscher R. Szoc.pol. Egy. Budapest

Etzkowitz, H., \& Leydesdorf, L.A. (1997). Universities and Global Knowledge Economy. A Triple Helix of University - Industry - Goverment Relations., Printer, London

Gáspár, L. (1998). Általános Innovációelmélet., Magyar Innovációs Szövetség, Budapest

Giffinger, R., Fertner, C., Kramar, H., Kalasek, R., Pichler-Milanovic, N., \& Meijers, E. (2007). Smart cities-Ranking of European medium-sized cities (Report). Vienna University of Technology. Retrieved from http://www.smartcities.eu/download/smart_cities_final_report.pdf.

International Organization for Standardization (2014) ISO 37120:2014 Sustainable development of communities - Indicators for city services and quality of life, Retrieved from https://www.iso.org/standard/62436.html

Kagermann H., Wahlster W., Helbring J. (2013). Securing the Future of German Manufacturing Industry: Recommendations for Implementing The Strategic Initiative Industrie 4.0. Final report of the Industrie 4.0 Working Group, Forshungsunion im Stifterverband für dir Deutsche Wirtschaft e.V., Berlin

Kondepudi, S. N., Ramanarayanan, V., Jain, A., Singh, G.N., Agarwal, N., Kumar, R., ...Menon, M. (2014). Smart sustainable cities: An analysis of definitions, The International Telecommunication Union Retrieved from https://www.itu.int/en/ITUT/focusgroups/ssc/Documents/Approved-Deliverables/TR-Definitions.docx

Lados, M., Horváthné, B. B. (2011), Smart cities tanulmány, MTA RKK NYUTI, Győr

Lengyel, I (2010). Regionális gazdaságfejlesztés, Akadémiai kiadó, Budapest

McKinsey \& Company (2013). How to make a city great. Retrieved from http://www.mckinsey.com/insights/urbanization/how_to_make_a_city_great

OECD (1996). The Knowledge-Based Economy. Organisation for Economic Co-operation and Development, Paris

Oslo Maual (2005). Guidelines for Collecting and Interpreting Innovation Data. The Measurement of Scientific and Technological Activities. Third Edition. A Joint Publication of OECD and Eurostat OECD, Paris

Rechnitzer, J, \& Smahó, M (2011). Területi politika. Dialóg Campus Kiadó, Budapest-Pécs.

Rechnitzer, J. (1993). Szétszakadás vagy felzárkózás. A térszerkezetet alakitó innovációk. MTA Regionális Kutatások Központja, Győr. 
Schoonmaker, R. (2014). Good Design Is Good Business. IBM Design Thinking. Retrieved from https:// www.ibm.com/developerworks/community/blogs/zTPF/entry/good_design is_good_business_ibm_design_thinking?lang=en.

Schumpeter, J. (1942). Capitalism, Socialism and Democracy. Harper \& Brothers

Schumpeter, J. (1980). A gazdasági fejlödés elmélete, Közgazdasági és jogi könyvkiadó, Budapest Soumitra, D., Bruno, L., and Sacha, W.V. (Eds.) (2017). The Global Innovation Index 2017

Startup Genome (2017) Global Startup Ecosystem Report 2017 https://startupgenome.com/report2017/

Startupgenome (2017): 2017 Global Startup Ecosystem Report Retrieved from https://startupgenome.com/thank-you-enjoy-reading/

The European Digital City Index (2016). The European Digital City Index Retrieved from: https://digitalcityindex.eu/

United Nations (2015): World Urbanization Prospects: The 2014 Revision, New York: United Nations Department of Economics and Social Affairs. Population Division 